\title{
Effects of ranibizumab and amfenac on the functional abilities and radiosensitivity of uveal melanoma cells
}

\author{
Efeitos do ranibizumabe e do amfenac nas habilidades funcionais e na \\ radiossensibilidade de células de melanoma uveal
}

\author{
Vasco Bravo-Filho',2,3, Patrick Logan', Pablo Zoroquiain', Sultan Aldrees', Natàlia Vilà', Ayman Oweida", \\ Rubens Belfort Neto², Miguel N. Burnier Jr',2 \\ 1. The Henry C. Witelson Ocular Pathology Laboratory, McGill University, Montreal, Quebec, Canada. \\ 2. Ophthalmology and Visual Sciences Department, Universidade Federal de São Paulo, São Paulo, SP, Brazil. \\ 3. Ophthalmology Department, Fundação Altino Ventura, Recife, PE, Brazil. \\ 4. Division of Radiation Oncology, McGill University, Montreal, Quebec, Canada.
}

\begin{abstract}
Purpose: To evaluate the effects of ranibizumab and amfenac in human uveal melanoma cell lines and to explore the ability of these compounds to sensitize uveal melanoma cells to radiation therapy. Methods: The 92.1 human uveal melanoma cell line was cultured and subjected to the proposed treatment (ranibizumab, amfenac, and a combination of both). Proliferation, migration, and invasion assays of the 92.1 uveal melanoma cell line were assessed after pretreatment with ranibizumab $(125 \mu \mathrm{g} / \mathrm{mL})$, amfenac $(150 \mathrm{nM})$, or a combination of both. In addition, proliferation rates were assessed after treatment with ranibizumab and amfenac, and the cells were subsequently exposed to various radiation doses (0, 4, and 8 Gy). Results: Proliferation assay: cells treated with a combination of ranibizumab and amfenac had lower proliferation rates than controls $(p=0.016)$ and than those treated with only ranibizumab $(p=0.033$ ). Migration assay: a significantly lower migration rate was observed in cells treated with amfenac than the control $(p=0.014)$ and than those treated with ranibizumab $(p=0.044)$. Invasion assay: there were no significant differences among the studied groups. Irradiation exposure: in the $4 \mathrm{~Gy}$ dose group, there were no significant differences among any groups. In the 8 Gy dose group, treatment with ranibizumab, amfenac, and their combination prior to application of the
\end{abstract}

Submitted for publication: November 14, 2017 Accepted for publication: May 19, 2018

Funding: This study was supported by the Pan-American Ophthalmology Association 2013 Sean Murphy Ocular Pathology Fellowship and by CAPES (Coordenação de Aperfeiçoamento Profissional de Nível Superior, Ministério da Educação/Brasil).

Disclosure of potential conflicts of interest: None of the authors have any potential conflicts of interest to disclose.

Corresponding author: Vasco Bravo-Filho

Rua Arnoldo Magalhães, 22/602 - Recife, PE - 52051-280 - Brazil

E-mail: vascobravofilho@yahoo.com.br

Approved by the following research ethics committee: UNIFESP/São Paulo Hospital (\# 3650271114).
8 Gy radiation led to a marked reduction in proliferation rates $(p=0.009, p=0.01$, and $p=0.034$, respectively) compared with controls. Conclusion: Combination of ranibizumab and amfenac reduced the proliferation rate of uveal melanoma cells; however, only amfenac monotherapy significantly decreased cell migration. The radiosensitivity of the 92.1 uveal melanoma cell line increased following the administration of ranibizumab, amfenac, and their combination. Further investigation is warranted to determine if this is a viable pretreatment strategy to render large tumors amenable to radiotherapy.

Keywords: Uveal melanoma; Ranibizumab; Cyclooxygenase-2; Radiation; Cell line

RESUMO | Objetivo: Avaliar os efeitos do ranibizumabe em associação com o amfenac nas células de melanoma uveal humano e explorar a capacidade desses compostos em sensibilizar as células de melanoma uveal à radioterapia. Métodos: Células de melanoma uveal humano do tipo 92.1 foram cultivadas e submetidas ao tratamento proposto (ranibizumabe, amfenac e a combinação de ambos). Ensaios de proliferação, migração e invasão com as células de melanoma uveal do tipo 92.1 foram avaliados após tratamento com ranibizumabe $(125 \mu \mathrm{g} / \mathrm{ml})$, amfenac (150 nM) e a combinação de ambos. Além disso, as taxas de proliferação foram avaliadas após tratamento com ranibizumabe e amfenac com subsequente exposição das células a diferentes doses de radiação (0 Gy, 4 Gy e 8 Gy). Resultados: Ensaio de proliferação: células tratadas com ranibizumabe e amfenac combinados apresentaram taxas de proliferação inferiores em comparação ao grupo controle $(p=0,016)$, do que as tratadas apenas com ranibizumabe $(p=0,033)$. Ensaio de migração: foi observada uma taxa de migração significativamente mais baixa nas células tratadas com amfenac do que no grupo controle $(p=0,014)$ e do que nas tratadas com ranibizumabe $(p=0,044)$. Ensaio de invasão: não houve diferenças significativas entre os grupos estudados. Exposição à irradiação: no grupo da dose de 4 Gy, não houve diferença significante entre os grupos. No grupo 
da dose de 8 Gy, o tratamento com ranibizumabe, afenac e sua combinação antes da aplicação da radiação de 8 Gy levou a uma redução acentuada nas taxas de proliferação $(p=0,009, p=0,01$ e $p=0,034$, respectivamente) em comparação aos grupos controle. Conclusão: A combinação de ranibizumabe e amfenac reduziu a taxa de proliferação das células de melanoma uveal; no entanto, apenas o amfenac diminuiu significativamente a migração celular. A radiossensibilidade das células de melanoma uveal do tipo 92.1 aumentou após a administração de ranibizumabe, amfenac e sua combinação. Mais investigações são necessárias para determinar se esta é uma estratégia de pré-tratamento viável para tornar grandes tumores passíveis de radioterapia.

Descritores: Melanoma uveal; Ranibizumabe; Inibidor da ciclooxigenase-2; Radiação; Linhagem celular

\section{INTRODUCTION}

Uveal melanoma (UM) is the most common primary intraocular tumor in adults. Despite the recent progress in treatment for these tumors, the mortality rate remains high $^{(1)}$. Furthermore, some tumors are too large on presentation to qualify for plaque radiation therapy, which is the standard treatment ${ }^{(2)}$. Therefore, there is a need for alternative treatment options.

Different types of cancer (colon carcinoma, stomach cancer, and soft tissue sarcoma) entail elevated serum concentrations of vascular endothelial growth factor $(\mathrm{VEGF})^{(3-5)}$. Recently, patients with UM have been shown to exhibit elevated levels of VEGF-A in both aqueous and vitreous humor ${ }^{(6)}$. Anti-VEGF treatment, administered through intravitreal injections, is currently one of the treatment modalities used for many eye conditions, with high rates of success and safety ${ }^{(7)}$.

Cyclooxygenase-2 (COX-2) expression has been reported in various of malignant tumors ${ }^{(8)}$, including $\mathrm{UM}^{(9)}$, where it was correlated with predictors of poor prognosis. An in vitro study reported a significantly decreased proliferation rate in UM cell lines following the administration of amfenac (a COX-2 inhibitor) ${ }^{(10)}$. It has long been suggested that prostaglandins, the products of cyclooxygenase $^{(11)}$ enzyme activity on arachidonic acid, play a role in cell survival after ionizing radiation. Both increased COX-2 protein, at doses as low as $2 \mathrm{~Gy}$, as well as selective COX-2 inhibitors are highly effective in enhancing tumor radioresponse ${ }^{(12)}$.

To the best of our knowledge, this is the first study evaluating the effects of ranibizumab and amfenac on the functional abilities of UM cells and on irradiation therapy.

In addition to investigating the effects of a combination of ranibizumab and amfenac in human UM cell lines, this study was conducted to test the ability of these compounds to sensitize UM cells to radiation therapy.

\section{METHODS}

The ranibizumab dose used during the experiments was selected based on the fact that the regular intravitreal dose of the medication is $0.50 \mathrm{mg}$ and the mean vitreous volume is $4 \mathrm{ml}$. Injecting $0.50 \mathrm{mg}$ of ranibizumab in a $4 \mathrm{ml}$ solution gives a concentration of $0.125 \mathrm{mg} / \mathrm{ml}$. The amfenac dose was selected based on previous studies using $150 \mathrm{nM}$ concentration, which is the $50 \%$ inhibitory activity of amfenac ${ }^{(13)}$.

We used the 92.1 human UM cell line established by Dr. Jager (University Hospital Leiden, Leiden, The Netherlands) ${ }^{(14)}$ because it is the most aggressive cell line according to the literature ${ }^{(15)}$. The cells were cultured using Roswell Park Memorial Institute media 1640 (Invitrogen, Ontario, Canada), with 5\% fetal bovine serum (FBS), $1 \%$ penicillin-streptomycin, and $1 \%$ amphotericin $\mathrm{B}$ to promote cell growth and prevent contamination following cell growth and two passages. Then, the cells were subjected to the proposed treatment (ranibizumab, amfenac, and a combination of both). The control group included cells that did not receive any treatment and those treated with dimethyl sulfoxide (DMSO), which is the recommended solvent for creating a liquid solution of amfenac powder. Proliferation (TC 20 automated cell counter; BioRad Laboratories, USA), migration $\left(\mathrm{QCM}^{\mathrm{TM}}\right.$ 24-Well Colorimetric Cell Migration Assay; EMD Millipore, USA), and invasion (Cell Invasion Assay Kit; EMD Millipore) of the 92.1 UM cell line were assessed after pretreatment with ranibizumab $(125 \mu \mathrm{g} / \mathrm{mL})$, amfenac (150 nM), or a combination of both compounds at these concentrations. The control group with and without DMSO during proliferation did not have significant difference; hence, we decided to use only the control group + DMSO as the control group for the other experiments.

Proliferation rates were assessed after treatment with ranibizumab, amfenac, or the combination as well as following subsequent radiation exposure. Radiation was performed using a clinical X-ray linear accelerator (Varian Inc.) with $6 \mathrm{MV}$ of energy and a radiation dose of $600 \mathrm{cGy} / \mathrm{min}$. After treatment with ranibizumab, amfenac, or the combination, the treated cells and control group were exposed to 0,4 , and 8 Gy of radiation, similar to that in a previous study ${ }^{(13)}$. A 3-(4,5-dimethylthiazol-2yl)-2,5-diphenyltetrazolium bromide (MTT) assay was used to assess the proliferation rates $48 \mathrm{~h}$ after radiation exposure; these values were compared with those of 
control cells (for both the compounds in combination with radiation and for radiation alone). MTT is a tetrazolium dye, and enzymes present in the cell culture are capable of reducing the dye into purple ${ }^{(16)}$. This assay is used for assessing cell metabolic activity ${ }^{(16)}$.

One-way analysis of variance was performed, and all analyses were performed using SPSS version 20 (IBM Corporation, USA). Student's $t$-test was used to determine the differences for all tests requiring the comparison of only two means (Microsoft Excel; Microsoft Corporation, USA). For all statistical analyses, a p-value of $<0.05$ was considered statistically significant.

The research protocol was approved by the Federal University of São Paulo (UNIFESP) Research and Ethical Committee.

\section{RESULTS}

The proliferation assay showed that cells treated with ranibizumab + amfenac (mean: 63,716.75 cells; SD: $12,713.90$ cells) had lower proliferation rates than the control + DMSO (mean: 82,555.50 cells; SD: 7,105.80 cells; $p=0.016$ ) and ranibizumab (mean: 80,825 cells; SD: $7,491.20$ cells; $p=0.033)$ groups. There were no significant differences between the amfenac (mean: 74,400 cells; SD: 4,888.20) group and the combination or control group. Additionally, no statistically significant differences were observed between the control (mean: 73,177.50 cells; SD: $12,546.06$ cells) and control + DMSO groups (Figure 1; Table 1).

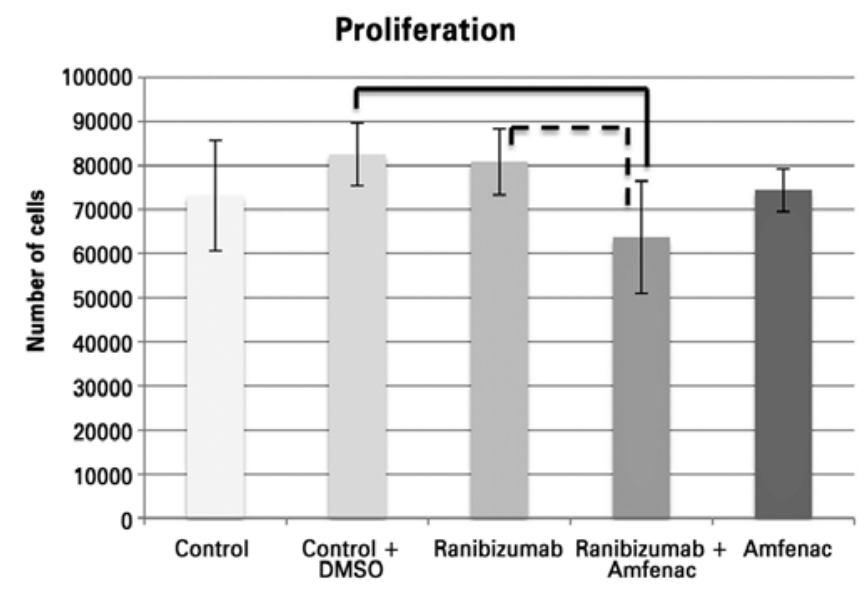

Continuous line: $P=0.016$ Dashed line: $P=0.033$

DMSO = dimethyl sulfoxide

Figure 1. Proliferation rates for all groups.
When the migration assay was performed, a significantly lower migration rate was observed only in the amfenac group (mean OD: 1.18944; SD: 0.0523) than in both the control + DMSO (mean OD: 1.97702; SD: 0.5141; $\mathrm{p}=0.014$ ) and ranibizumab (mean OD: 1.832585; SD: $0.022175 ; p=0.044$ ) groups. The control group had a higher migration rate than all other groups. The combination group (mean OD: 1.56848; SD: 0.01715) did not exhibit statistically significant differences from the other treatment conditions (Figure 2; Table 2). There were no significant differences among the studied groups in the invasion assay $(p=0.27$; Figure 3$)$.

After irradiation exposure, the 0 Gy group treated with ranibizumab alone (mean OD: 1.268553387; SD: 0.21058014 ) and amfenac alone (mean OD: 1.174443046; SD: 0.105847858) showed a significantly lower proliferation rate than the controls (mean OD: 1.618110359;

Table 1. Proliferation rate $P$-values for all groups

\begin{tabular}{lcc}
\hline & Treatment group & $P$-value \\
\hline Control & Control + DMSO & 0.444 \\
& Ranibizumab & 0.635 \\
& Ranibizumab + Amfenac & 0.436 \\
Control + DMSO & Amfenac & 0.999 \\
& Ranibizumab & 0.999 \\
Ranibizumab & Ranibizumab + Amfenac & 0.016 \\
& Amfenac & 0.578 \\
Ranibizumab + Amfenac & Ranibizumab + Amfenac & 0.033 \\
\hline DMSO= dimethyl sulfoxide. & Amfenac & 0.766 \\
\hline
\end{tabular}

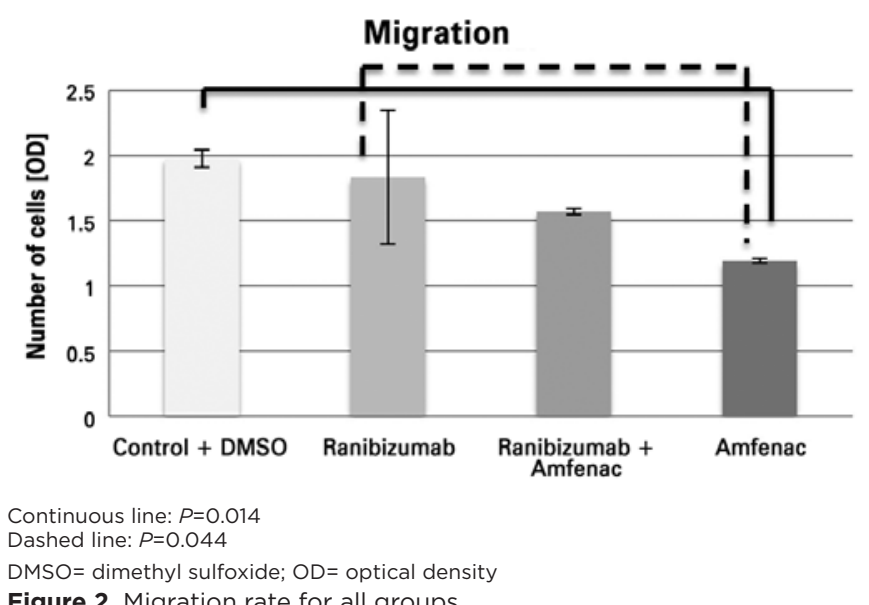


Table 2. Migration rate $P$-values for all groups

\begin{tabular}{lcc}
\hline & Treatment group & $P$-value \\
\hline Control + DMSO & Ranibizumab & 0.937 \\
& Ranibizumab + Amfenac & 0.275 \\
& Amfenac & 0.014 \\
Ranibizumab & Ranibizumab + Amfenac & 0.649 \\
Ranibizumab + Amfenac & Amfenac & 0.044 \\
\hline
\end{tabular}

$\mathrm{DMSO}=$ dimethyl sulfoxide.

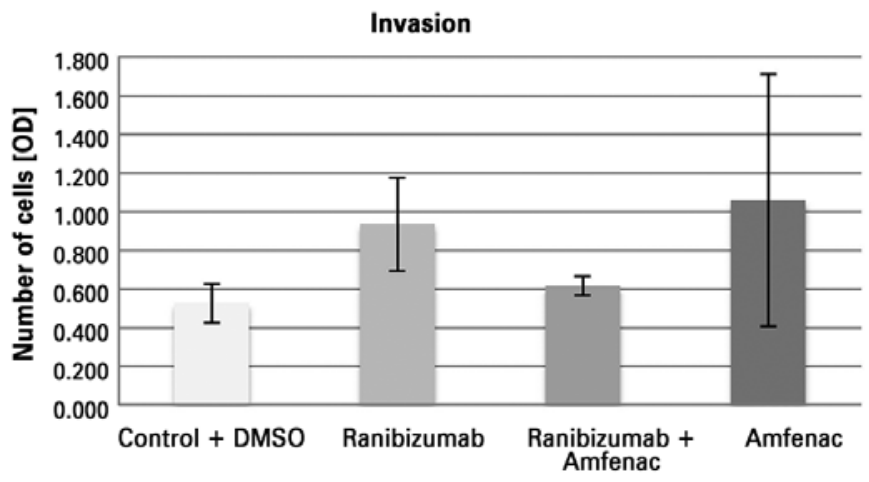

DMSO= dimethyl sulfoxide; OD= optical density

Figure 3. Invasion rate for all groups.

SD: $0.15628323, p=0.048$ and 0.01 , respectively). The combination group (mean OD: 1.395466552; SD: 0.179066171 ) did not present a statistically significant difference compared with the control group $(p=0.319)$. Additionally, there were no differences between the ranibizumab and combination groups $(p=0.788)$ or between the ranibizumab and amfenac groups $(p=0.914)$. In the 4 Gy group, there were no significant differences among the conditions (Table 3). In the 8 Gy group, treatment with ranibizumab, amfenac, and a combination of both prior to application of the 8 Gy radiation dose led to a marked reduction in proliferation rates $(p=0.009,0.01$, and 0.034 , respectively) compared with the control group. There were no statistically significant differences between the three treatment groups for the 8 Gy radiation (Table 4). Analysis of the differences between each condition according to the irradiation dose showed that the ranibizumab and combined groups had significantly lower proliferation rates at 8 Gy than those at 4 Gy $(p=0.022$ and 0.001 , respectively). The ranibizumab and combined groups had also significantly lower proliferation rates at 8 Gy than those at 0 Gy $(p=0.022$ and 0.001 , respectively). In the control group, significantly
Table 3. The mean OD, SD, and P-values for the group treated with the 4 Gy radiation dose

\begin{tabular}{|c|c|c|}
\hline 4 Gy irradiation dose & Mean OD (SD) & Treatment group ( $P$-value) \\
\hline \multirow[t]{3}{*}{ Control + DMSO } & 1.298956337 & Ranibizumab (0.738) \\
\hline & $(0.224925566)$ & $\begin{array}{c}\text { Ranibizumab }+ \text { Amfenac } \\
(0.967)\end{array}$ \\
\hline & & Amfenac (0.920) \\
\hline \multirow[t]{2}{*}{ Ranibizumab } & 1.440193767 & $\begin{array}{c}\text { Ranibizumab }+ \text { Amfenac } \\
(0.974)\end{array}$ \\
\hline & $(0.087934204)$ & Amfenac (0.292) \\
\hline \multirow[t]{2}{*}{ Ranibizumab + Amfenac } & 1.372118918 & Amfenac (0.604) \\
\hline & $(0.08864664)$ & \\
\hline \multirow[t]{2}{*}{ Amfenac } & 1.204180278 & \\
\hline & $(0.248646747)$ & \\
\hline
\end{tabular}

$\mathrm{DMSO}=$ dimethyl sulfoxide; $\mathrm{OD}=$ optical density

Table 4. The mean OD, SD, and $P$-values for the group treated with the 8 Gy dose

\begin{tabular}{lcc}
\hline 8 Gy irradiation dose & Mean OD (SD) & Treatment group ( $P$-value) \\
\hline Control + DMSO & $\begin{array}{l}1.12659663 \\
(0.060960288)\end{array}$ & $\begin{array}{c}\text { Ranibizumab (0.009) } \\
\text { Ranibizumab + Amfenac (0.01) }\end{array}$ \\
\hline Ranibizumab & $\begin{array}{c}0.924039709 \\
(0.110233575)\end{array}$ & Ranibizumab + Amfenac (1.0) \\
Ranibizumab + Amfenac & 0.926620053 & Amfenac (0.959) \\
& $(0.02127271)$ & Amfenac (0.969) \\
Amfenac & 0.958493901 & \\
& $(0.098401276)$ & \\
\hline
\end{tabular}

$\mathrm{DMSO}=$ dimethyl sulfoxide; $\mathrm{OD}=$ optical density.

lower proliferation rates were observed at 4 and 8 Gy than at $0 \mathrm{~Gy}$ ( $p=0.05$ and 0.005 , respectively). The group treated with amfenac alone did not exhibit any significant differences compared with the groups treated with different irradiation doses (Figure 4).

\section{DISCUSSION}

Despite the advancements in its treatment and diagnosis, UM remains a challenge because appropriate treatment does not prevent the development of metastases in some patients ${ }^{(17)}$. Moreover, when the tumor is very large, brachytherapy is insufficient for reducing the lesion, and enucleation is necessary for some patients ${ }^{(2)}$.

Ranibizumab and amfenac are well-established drugs in the field of ophthalmology, and their use has been approved by the United States Food and Drug Administration ${ }^{(18,19)}$. As such, proving the effect of these medications on UM may hasten its adoption for patient use. Therefore, experiments testing the usefulness and efficacy of well-known drugs developed for other purposes are important to evaluate if they will helpful for the patient management. 


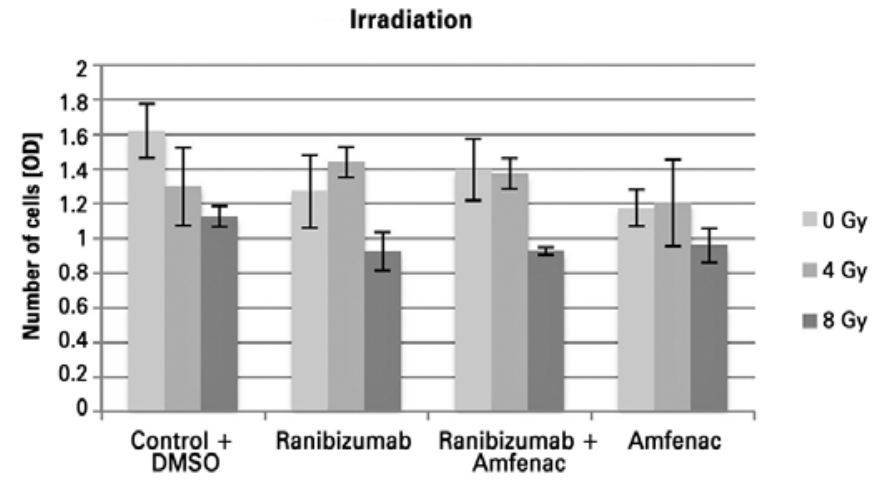

DMSO = dimethyl sulfoxide; $O D=$ optical density

Figure 4. Irradiation exposure assay for all groups

The isolated use of anti-VEGF therapy was not as effective as expected; however, when associated with other therapies acting against cancer, the results were better than those of the isolated treatment ${ }^{(7,20)}$. Angiogenesis deregulation is one of the most critical changes in the cancer environment, and it elicits modifications to the tumor's microvasculature, which is responsible for reducing the efficacy of chemotherapy, radiotherapy, and immunotherapy ${ }^{(21)}$. One of the hypotheses related to the benefits of an anti-VEGF drug is that such agents can attenuate vascular hyperpermeability, increase vessel pericytes, improve the basal membrane structure with consequent hypoxia, and reduce interstitial fluid pressure $^{(21)}$. All of these changes can improve the delivery and efficacy of chemotherapy, radiotherapy, and immunotherapy.

In this study, only the combination of ranibizumab and amfenac had inhibitory effects on the proliferation rate of 92.1 cells compared with the control group. This is the first time this finding has been described. We expected ranibizumab alone to have a significant effect because Logan et al. had described a reduction in 92.1 cell proliferation following treatment with bevacizu$\mathrm{mab}^{(22)}$. However, the combination of an anti-VEGF agent with a COX-2 inhibitor significantly reduced proliferation of the 92.1 cells. Administering both drugs in combination may have had a greater effect because they act on different pathways. Our findings were different from those of Li et al. ${ }^{(23)}$. In their study, ranibizumab had an inhibitory effect in UM cells when administered alone at a dose of $250 \mu \mathrm{g} / \mathrm{mL}$, which reduced the survival rate to $57 \%$, whereas our study only showed similar effects for the combination treatment. Another difference was that we used a well-established UM cell line, whereas
Li et al. extracted cells from a ciliary body melanoma. It is not possible to evaluate whether these differences resulted from the different doses or different cell types; therefore, other studies using other cell types with different aggressive behaviors as well as administration of different doses are important to elucidate this variance.

COX-2 is speculated to have an anti-VEGF effect, corroborating the idea that both drugs administered in combination could have additional VEGF-blocking effects ${ }^{(24)}$. Logan et al. demonstrated that the 92.1 cell line could produce the primary VEGF-A receptor, VEGF-R2, suggesting that the cytokine and its receptor could be involved in tumor development and progression. This highlights the autocrine effect in this tumor and the importance of having different methods for blocking VEGF pathways, avoiding the cytokines that contribute to the proliferation of tumor cells ${ }^{(24)}$.

$\mathrm{UM}$ is a tumor that can present circulating malignant cells even after irradiation therapy or enucleation ${ }^{(25)}$. Therefore, better understanding of a UM cell's migration and invasion abilities will help in the development of new approaches to metastasis treatment; this remains a significant challenge when managing UM patients ${ }^{(26)}$. Use of the correct cell lines is important for better knowledge of the functional abilities of UM cells. Hence, we used the 92.1 cell line because it is derived from primary UM and not from metastatic tumors ${ }^{(27)}$.

We demonstrated, for the first time, that amfenac can significantly reduce the migration rate of 92.1 cells. The ranibizumab and combined groups also exhibited a decreased migration rate but this was not significant. The results highlighted the importance of VEGF and COX-2 in the metastasis pathway because blockage of these targets affects cell migration.

Evaluation of the UM cell invasion rate showed an insignificant difference among the groups. In fact, the cells that received any treatment exhibited an increased invasion rate. Additional research is needed to better understand these effects, and we suggest employing a measure of angiogenic factors in culture media to enable the quantification of the cytokines involved in the experiment.

Amfenac has been proven to increase the radiosensitivity of UM cell lines ${ }^{(13)}$, including the 92.1 cell line used in the present study. We observed that at an 8 Gy irradiation dose, the three treatment groups exhibited a significantly decreased proliferation rate compared with the control, demonstrating the capacity of these drugs to increase the radiosensitivity of the 92.1 UM cells. Both ranibizumab and combination therapy appeared 
to be better at increasing the sensitivity of UM cells to irradiation compared with amfenac alone, although this increase was not significant. Low-dose irradiation has been shown to increase COX-2 levels ${ }^{(13)}$; we were able to improve the response of the tumor to irradiation using a COX-2 inhibitor. As previously mentioned, this was the first time that the effect of an anti-VEGF drug was tested in association with irradiation against human UM cells. Schwannomas are typically treated with radiation; however, combining radiation with bevacizumab yields increased efficacy and decreased radiation-induced hearing loss, showing the importance of using combined therapies to improve results while reducing adverse effects ${ }^{(28)}$. Amfenac also showed important effects as an adjuvant therapy because the drug was able to protect human fibroblasts from the effects of irradiation ${ }^{(13)}$. Therefore, both drugs tested in our experiment hold immense potential as adjuvant therapies for UM.

Despite the improvements in brachytherapy, the patient's vision is impaired in 35\% of cases within 5 years and in $68 \%$ of cases at the 10 -year follow up, because thicker tumors are associated with worsening visual acuity ${ }^{(29)}$. Therefore, combined therapies can reduce the number of complications associated with brachytherapy, particularly those related to vision loss, such as radiation-induced retinopathy or neovascular glaucoma ${ }^{(18)}$. Combined therapies can even increase the indication of brachytherapy with consequent enucleation reduction because the drugs can increase tumor cell radiosensitivity. The importance of reducing the enucleation rate and occurrence of visual impairment has been highlighted in the literature, particularly because these effects can lead to higher levels of anxiety and depression among patients who undergo enucleation or develop worsening vision $^{(30)}$.

Future research should employ an animal model to evaluate the effects of ranibizumab and amfenac, both in isolation and in combination with radiation therapy, to assess the outcomes in vivo and to clarify whether using them together can prevent tumor growth.

The combination of ranibizumab and amfenac reduced the proliferation rate of UM cells. However, only amfenac monotherapy significantly reduced cell migration. None of the medications tested affected the invasion rate of the 92.1 cells. The radiosensitivity of the 92.1 UM cell line increased following the administration of ranibizumab, amfenac, and combination therapy.

This represents the first report in the literature to show the effects of ranibizumab, amfenac, and a combination of these on the functional abilities and radiosensitivity of 92.1 UM human cells. Further investigation is warranted to determine whether this approach is a viable pretreatment strategy that can render large tumors amenable to radiotherapy or to determine whether this therapy will improve the management of patients with UM.

\section{REFERENCES}

1. Singh AD, Topham A. Survival rates with uveal melanoma in the United States: 1973-1997. Ophthalmology. 2003;110(5):962-5.

2. Vasalaki M, Fabian ID, Reddy MA, Cohen VM, Sagoo MS. Ocular oncology: advances in retinoblastoma, uveal melanoma and conjunctival melanoma. Br Med Bull. 2017;121(1):107-19.

3. Bestas R, Kaplan MA, Isikdogan A. The correlation between serum VEGF levels and known prognostic risk factors in colorectal carcinoma. Hepatogastroenterology. 2014;61(130):267-71.

4. Wang L, Chang Y, Xu J, Zhang Q. Predictive significance of serum level of vascular endothelial growth factor in gastric cancer patients. Biomed Res Int. 2016;2016:8103019.

5. Schiavetti A, McDowell HP, Conti L, Altavista P, Antenucci A, Pizer $B$, et al. Vascular endothelial growth factor serum levels in children with newly diagnosed rhabdomyosarcoma. Pediatr Blood Cancer. 2012;59(4):627-30.

6. Boyd SR, Tan D, Bunce C, Gittos A, Neale MH, Hungerford JL, et al. Vascular endothelial growth factor is elevated in ocular fluids of eyes harbouring uveal melanoma: identification of a potential therapeutic window. Br J Ophthalmol. 2002;86(4):448-52.

7. Cobleigh MA, Langmuir VK, Sledge GW, Miller KD, Haney L, Novotny WF, et al. A phase $\mathrm{l} / \mathrm{ll}$ dose-escalation trial of bevacizumab in previously treated metastatic breast cancer. Semin Oncol. 2003;30(5 Suppl 16):117-24.

8. Soumaoro LT, Uetake H, Higuchi T, Takagi Y, Enomoto M, Sugihara K. Cyclooxygenase-2 expression: a significant prognostic indicator for patients with colorectal cancer. Clin Cancer Res. 2004;10(24): 8465-71.

9. Figueiredo A, Caissie AL, Callejo SA, McLean IW, Gold P, Burnier MN Jr. Cyclooxygenase-2 expression in uveal melanoma: novel classification of mixed-cell-type tumours. Can J Ophthalmol. 2003; 38(5):352-6.

10. Marshall JC, Caissie AL, Cruess SR, Cools-Lartigue J, Burnier MN Jr. The effects of a cyclooxygenase-2 (COX-2) expression and inhibition on human uveal melanoma cell proliferation and macrophage nitric oxide production. J Carcinog. 2007;6(1):17.

11. Liao Z, Komaki R, Milas L, Yuan C, Kies M, Chang JY, et al. A phase I clinical trial of thoracic radiotherapy and concurrent celecoxib for patients with unfavorable performance status inoperable/unresectable non-small cell lung cancer. Clin Cancer Res. 2005;11(9):3342-8.

12. Davis TW, Hunter N, Trifan OC, Milas L, Masferrer JL. COX-2 inhibitors as radiosensitizing agents for cancer therapy. Am J Clin Oncol. 2003;26(4):S58-61.

13. Fernandes BF, Marshall JC, Di Cesare S, Logan P, Maloney S, Burnier MN Jr. Amfenac increases the radiosensitivity of uveal melanoma cell lines. Eye (Lond). 2008;22(5):701-6.

14. De Waard-Siebinga I, Blom DJ, Griffioen M, Schrier PI, Hoogendoorn E, Beverstock G, et al. Establishment and characterization of an uveal-melanoma cell line. Int J Cancer. 1995;62(2):155-61.

15. Marshall JC, Caissie AL, Callejo SA, Antecka E, Burnier Jr MN. Cell proliferation profile of five human uveal melanoma cell lines of different metastatic potential. Pathobiology. 2004;71(5):241-5. 
16. Berridge MV, Herst PM, Tan AS. Tetrazolium dyes as tools in cell biology: new insights into their cellular reduction. Biotechnol Annu Rev. 2005;11:127-52.

17. Kaliki S, Shields CL. Uveal melanoma: relatively rare but deadly cancer. Eye (Lond). 2017;31(2):241-57.

18. Dunavoelgyi R, Zehetmayer M, Simader C, Schmidt-Erfurth U. Rapid improvement of radiation-induced neovascular glaucoma and exudative retinal detachment after a single intravitreal ranibizumab injection. Clin Experiment Ophthalmol. 2007;35(9):878-80.

19. Lindstrom R, Kim T. Ocular permeation and inhibition of retinal inflammation: an examination of data and expert opinion on the clinical utility of nepafenac. Curr Med Res Opin. 2006;22(2):397-404.

20. Giantonio BJ, Catalano PJ, Meropol NJ, O’Dwyer PJ, Mitchell EP, Alberts SR, et al. Eastern Cooperative Oncology Group Study E3200. Bevacizumab in combination with oxaliplatin, fluorouracil, and leucovorin (FOLFOX4) for previously treated metastatic colorectal cancer: results from the Eastern Cooperative Oncology Group Study E3200. J Clin Oncol. 2007;25(12):1539-44.

21. Goel S, Duda DG, Xu L, Munn LL, Boucher Y, Fukumura D, et al. Normalization of the vasculature for treatment of cancer and other diseases. Physiol Rev. 2011;91(3):1071-121.

22. Logan P, Burnier J, Burnier MN Jr. Vascular endothelial growth factor expression and inhibition in uveal melanoma cell lines. Ecancermedicalscience. 2013;7:336.

23. Li J, Cui Y, Wang Q, Guo D, Pan X, Wang X, et al. The proliferation of malignant melanoma cells could be inhibited by ranibizumab via antagonizing VEGF through VEGFR1. Mol Vis. 2014;20:649-60.
24. Yanni SE, Clark ML, Yang R, Bingaman DP, Penn JS. The effects of nepafenac and amfenac on retinal angiogenesis. Brain Res Bull. 2010;81(2-3):310-9.

25. Callejo SA, Antecka E, Blanco PL, Edelstein C, Burnier MN Jr. Identification of circulating malignant cells and its correlation with prognostic factors and treatment in uveal melanoma. A prospective longitudinal study. Eye (Lond). 2007;21(6):752-9.

26. Hawkins BS; Collaborative Ocular Melanoma Study Group. The Collaborative Ocular Melanoma Study (COMS) randomized trial of pre-enucleation radiation of large choroidal melanoma: IV. Ten-year mortality findings and prognostic factors. COMS report number 24. Am J Ophthalmol. 2004;138(6):936-51.

27. Griewank KG, Yu X, Khalili J, Sozen MM, Stempke-Hale K, Bernatchez $\mathrm{C}$, et al. Genetic and molecular characterization of uveal melanoma cell lines. Pigment Cell Melanoma Res. 2012;25(2):182-7.

28. Zhang N, Gao X, Zhao Y, Datta M, Liu P, Xu L. Rationally combining anti-VEGF therapy with radiation in NF2 schwannoma. J Rare Dis Res Treat. 2016;1(2):51-5.

29. Shields CL, Shields JA, Cater J, Gündüz K, Miyamoto C, Micaily B, et al. Plaque radiotherapy for uveal melanoma: long-term visual outcome in 1106 consecutive patients. Arch Ophthalmol. 2000; 118(9):1219-28.

30. Melia M, Moy CS, Reynolds SM, Hayman JA, Murray TG, Hovland KR, et al. Collaborative Ocular Melanoma Study-Quality of Life Study Group. Quality of life after iodine 125 brachytherapy vs enucleation for choroidal melanoma: 5-year results from the Collaborative Ocular Melanoma Study: COMS QOLS Report No. 3. Arch Ophthalmol. 2006;124(2):226-38. 